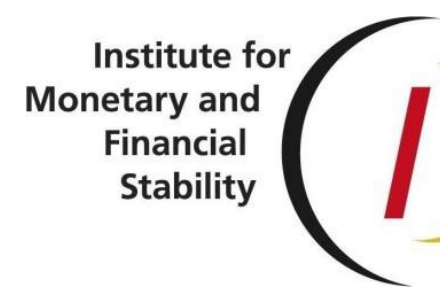

ATHANASIOS ORPHANIDES

\title{
Fiscal Implications \\ of Central Bank Balance Sheet Policies
}

Institute for Monetary and Financial Stability

GOETHE UNIVERSITY FRANKFURT AM MAIN 
This Working Paper is issued under the auspices of the Institute for Monetary and Financial Stability (IMFS). Any opinions expressed here are those of the author(s) and not those of the IMFS. Research disseminated by the IMFS may include views on policy, but the IMFS itself takes no institutional policy positions.

The Institute for Monetary and Financial Stability aims at raising public awareness of the importance of monetary and financial stability. Its main objective is the implementation of the "Project Monetary and Financial Stability" that is supported by the Foundation of Monetary and Financial Stability. The foundation was established on January 1, 2002 by federal law. Its endowment funds come from the sale of $1 \mathrm{DM}$ gold coins in 2001 that were issued at the occasion of the euro cash introduction in memory of the D-Mark.

The IMFS Working Papers often represent preliminary or incomplete work, circulated to encourage discussion and comment. Citation and use of such a paper should take account of its provisional character.

\section{Institute for Monetary and Financial Stability}

Goethe University Frankfurt

House of Finance

Theodor-W.-Adorno-Platz 3

D-60629 Frankfurt am Main

www.imfs-frankfurt.de I info@imfs-frankfurt.de 


\title{
Fiscal Implications of Central Bank Balance Sheet Policies
}

\author{
Athanasios Orphanides* \\ MIT
}

July 2016

\begin{abstract}
Under ordinary circumstances, the fiscal implications of central bank policies tend to be seen as relatively minor and escape close scrutiny. The global financial crisis of 2008, however, demanded an extraordinary response by central banks which brought to light the immense power of central bank balance sheet policies as well as their major fiscal implications. Once the zero lower bound on interest rates is reached, expanding a central bank's balance sheet becomes the central instrument for providing additional monetary policy accommodation. However, with interest rates near zero, the line separating fiscal and monetary policy is blurred. Furthermore, discretionary decisions associated with asset purchases and liquidity provision, as well as with lender-of-last-resort operations benefiting private entities, can have major distributional effects that are ordinarily associated with fiscal policy. In the euro area, discretionary central bank decisions can have immense distributional effects across member states. However, decisions of this nature are incompatible with the role of unelected officials in democratic societies. Drawing on the response to the crisis by the Federal Reserve and the ECB, this paper explores the tensions arising from central bank balance sheet policies and addresses pertinent questions about the governance and accountability of independent central banks in a democratic society.
\end{abstract}

Keywords: Quantitative easing, lender of last resort, monetary financing, loss sharing, central bank independence, central bank accountability, central bank governance, rules vs discretion.

JEL Classification: E52, E58, E61, G01, H12.

* This article is based on the author's presentations at the Council for Budget Responsibility conference on Rethinking Fiscal Policy After the Crisis on 11 September 2015 in Bratislava and the Banco de Espana conference on Fiscal Sustainability, XXI Century on 6 June 2016 in Madrid. I would like to thank Charles Calomiris, Stephen Cecchetti, Marvin Goodfriend, Charles Goodhart, Gregory Hess, Patrick Honohan, George Kopits and Ludovit Odor for helpful discussions, suggestions and comments.

Correspondence: MIT Sloan School of Management, E62-481, 100 Main Street, Cambridge, MA 02142. Tel.: +1-617-324-4051. E-mail: athanasios.orphanides@mit.edu 


\section{Introduction}

In the aftermath of the 2008 global financial crisis, central banks have been called on to undertake unprecedented responsibilities well beyond ordinary monetary policy operations aiming to preserve price stability. In large part, this reflected the ability of central banks to generate rapidly the equivalent of fiscal resources, through the creation of high-powered money. These resources could be used for asset purchases and bailout operations without the delays associated with fiscal deliberations in democracies and served a useful role in containing some adverse effects of the crisis. In the process, it was also revealed that the power of a central bank's balance sheet can be more massive and awe-inspiring than the prevailing understanding before the crisis.

Although monetary arithmetic ultimately links fiscal and monetary policy (Sargent and Wallace, 1981), prior to the crisis the fiscal implications of central bank policies tended to be seen as relatively minor and escaped close scrutiny. This served a useful political purpose:

Underemphasizing the fiscal consequences of central bank decisions could more easily sustain support for an independent central bank with discretionary powers and a price stability mandate. During the crisis, however, near zero interest rates blurred the line separating fiscal and monetary policy and bailout operations drew attention to fiscal consequences and distributional implications of balance sheet policies. This, in turn, raised questions about the institutional division of labor between independent central banks and elected governments.

The response to the crisis by the Federal Reserve and the ECB, the central banks of the world's two largest economies, included discretionary decisions with immense distributional effects that could be seen as incompatible with the role of unelected officials in democratic societies. For both central banks, issues arose with decisions that resulted in the preferential treatment of specific sectors of the economy or specific private interests. In the case of the ECB, support to different euro area member states appears to have been decidedly uneven during the crisis, as a result of discretionary decisions.

After a review of the historical antecedents and the pre-crisis consensus regarding the institutional design of central banks and their policies, this paper examines some of the decisions taken by the Federal Reserve and the ECB during the crisis in the context of their role as independent central banks in a democratic society. The examples discussed raise questions that challenge the legitimacy of the use of discretion: Is the proper function of an independent central bank in a democratic society to use its discretion and decide which sectors of the economy deserve the support of its balance sheet and which don't? Does an independent central bank have the legitimacy to discriminate in favor of specific private interests and against others? In a monetary union, does the central bank have the legitimacy to take discretionary decisions that 
favor specific member states over others or decisions that penalize member states for what the central bank views as moral-hazard-induced actions by democratically elected governments?

The paper concludes with a discussion about the potential resolution of the legitimacy problem that has arisen due to central bank actions during the crisis.

\section{Historical antecedents and the pre-crisis consensus}

Modern central banks, certainly those operating in Europe and North America, identify price stability, economic stability and financial stability as their key goals and the reason for their existence as independent policy institutions. Indeed, the typical textbook treatment would discuss monetary policy as aiming to achieve these objectives without discussion of fiscal consequences of central bank decisions in pursuit of these goals.

However, this is neither an accurate reflection of the origins of central banking nor does it do justice to the intimate potential links between central bank policies and the fiscal affairs of the state. ${ }^{1}$ Financing the state, particularly during war, was perhaps the single most important early factor in the development of central banking. One of the oldest central banks, the Bank of England, was founded in 1694 and was granted monopoly on note issuance to provide financing to King William III. Napoleon Bonaparte founded Banque de France in 1800 to facilitate his government's finance. In North America, the Federal Reserve Board was founded in 1913 to provide an elastic currency in response to financial crises so state financing was not an explicit reason for its founding. Nonetheless, the Federal Reserve's most important task during the first years of its operations was none other but to facilitate the financing of World War I.

Controlling the issue and use of currency is a powerful economic weapon that can be used during times of peace and war to extract resources from the economy and, on occasion, even to wage economic warfare. Seignorage, the real value accruing to the issuer of currency notes, can be a significant source of fiscal revenue, an invisible tax. In modern economies with low and stable inflation, seignorage is small but it need not be negligible. Seignorage can easily exceed $1 \%$ of GDP per year in economies with high inflation. During the early 1980s, seignorage exceeding $5 \%$ of GDP was documented in countries such as Mexico and Russia. ${ }^{2}$ Empirical estimates suggest that seignorage can be maximized at inflation rates exceeding $100 \%$ per year, which suggests obvious tradeoffs given the detrimental effects of high inflation to growth and welfare. ${ }^{3}$

\footnotetext{
${ }^{1}$ Goodhart (2010) provides a brief review of the changing role of central banks over time. Orphanides (2014c) discusses the evolving role of the Federal Reserve.

${ }^{2}$ See Hawkins (2003) for historical information regarding seignorage and central bank profit distributions

${ }^{3}$ Fischer et al (2002) present empirical estimates of the seignorage-maximizing inflation rate and discuss the welfare tradeoffs involved.
} 
In addition to extracting seignorage through inflation, the central bank balance sheet can be used to secure favorable financing terms for government debt. The cost of financing for the government can be reduced with financial repression-through regulation of the financial sector. Financial repression also entails tradeoffs as the redirection of resources for the benefit of the government restricts credit to the private sector that could have been otherwise allocated to investment. Like seignorage, financial repression can be detrimental to growth and welfare.

A sovereign nation in control of money issuance can have immense power on the fiscal resources that can be extracted through the central bank. The debasement of money can be systematically abused, a problem that has been well recognized in the history of central banking. In 1824, David Ricardo identified the issue as follows:

"It is said that Government could not be safely entrusted with the power of issuing paper money; that it would most certainly abuse it; and that, on any occasion when it was pressed for money to carry on a war, it would cease to pay coin, on demand, for its notes; and from that moment the currency would become a forced Government paper. There would, I confess, be great dangers of this, if Government - that is to say, the Ministerswere themselves to be entrusted with the power of issuing paper money” (Ricardo, 1824).

Ricardo drew important lessons regarding the governance of the central bank. In his view, the institution entrusted with the issuance of money should be kept independent of the government in order to safeguard the value of money and avoid the potential abuse associated with its issuance.

The pre-crisis consensus on central bank design captured Ricardo’s reasoning by recognizing both the need of central bank independence from the fiscal authority as well as the need to protect the central bank from becoming the de facto source of financing for the government-the latter taking the form of the "no monetary financing” clause seen in central bank legislation.

In democracies, ensuring that central banks remain independent from the elected government provides a solution to the dynamic inconistency problems associated with intertemporal tradeoffs. Price stability without financial repression encourages growth and improves welfare in the long run. On the other hand, faster money creation offers short-term gains: It can raise seignorage and employment. The costs come later with lower credibility and higher inflation. Higher prices also reduce the real value of outstanding nominal government debt. The incentives for governments wishing to improve the odds of their reelections are to focus on the shorter end of the spectrum of the cost-benefit analysis. By maintaining a long-term focus, an independent central bank with a price stability objective and support of a market-based economy, refraining from financial repression, can better facilitate growth and welfare over time. 
Monetary policy decisions always have some fiscal implications and distributional consequences. By influencing the path of real interest rates over time, monetary policy decisions have an impact on the intertemporal fiscal burden of the government and on the relative returns enjoyed by savers and lenders in the economy. However, under ordinary circumstances and as long as monetary policy aims to ensure price stability and economic stability, these effects can be ignored as the unavoidable secondary side effects of policies that aim at society's broader good.

Central bank policies could and normally should aim to minimize any distributional effects and credit allocation distortions introduced by their policies to avoid encroaching on matters that are incompatible with the role of unelected officials in democratic societies. Overall, the central bank should encourage free markets to allocate capital efficiently and promote growth and welfare over time, without engaging in operations that might suggest a bias in favor of regions or sectors of the economy, even though some distributional effects may be unavoidable.

\section{The power of a central bank's balance sheet}

In the aftermath of the 2008 global financial crisis, central banks have been called on to undertake unprecedented responsibilities well beyond ordinary monetary policy operations. Central banks were overburdened and seen as "the only game in town" (Orphanides, 2013). In large part, this reflected the ability of central banks to act quickly—specifically generate the equivalent of fiscal resources rapidly through the creation of high-powered money (currency and reserves). In part, central banks acted to fill a void created by the hesitation of fiscal authorities to act in a resolute manner but in doing so tested the limits of democratic legitimacy. ${ }^{4}$ Central banks certainly averted the worst of outcomes feared at the beginning of the crisis but their actions during the crisis also revealed that the power of a central bank's balance sheet can be more massive and awe-inspiring than what was the prevailing understanding before the crisis, at least outside the circles of central bank policy experts.

Actions were wide-ranging. Central banks engaged in unconventional monetary policy, including the purchase of public and private assets and the expanded provision of liquidity at low interest rates upon presentation of collateral drawn from a broadened base-collateral that would not have qualified for pre-crisis operations. Central banks also engaged in preferential lending operations: Lending to government-related or other entities at terms not available to others in the economy. Perhaps most controversial, in some cases central banks became the central actors in bailout operations: Lending to potentially insolvent private firms or government entities with compromised market access.

\footnotetext{
${ }^{4}$ Buiter(2014) and Tucker(2015, 2016) present expositions of the legitimacy and accountability challenges that have been exposed as a result of central bank actions over the past several years
} 
Examined in isolation, none of these operations should be seen as necessarily peculiar or problematic. However, many of the decisions taken by central banks during the crisis were not simple applications of established rules or principles but rather were of a discretionary nature. Given the fiscal dimension and distributional consequences of such discretionary decisions, these balance sheet policies raise questions about the governance and accountability of independent central banks in a democratic society.

\section{III.1 Unconventional monetary policy}

When policy interest rates are lowered near zero, additional monetary policy accommodation can be provided, if needed, by expanding the central bank's balance sheet. ${ }^{5}$ Asset purchases become a crucial monetary policy tool. Purchases of government bonds-what is known as quantitative easing (QE) — has been recognized as an extension of conventional monetary policy easing at the zero lower bound at least since the 1930s. ${ }^{6}$ QE lowers real interest rates at longer maturities than those constrained by the zero lower bound, thereby easing monetary conditions despite the constraint on short-term rates.

As overnight interest rates may be constrained near zero, the extent of monetary policy easing is no longer reflected in policy rates alone. The size of the balance sheet of the central bank becomes a useful summary indicator of policy accommodation, similar to the role of the overnight rate under ordinary circumstances. As with conventional easing, of course, no single indicator is sufficient to capture the degree of monetary accommodation in the economy.

The experience of the Federal Reserve and the ECB since 2008 serves as an illustration. Figures 1 through 5 outline a comparison of the conditions faced by and the policies pursued by the Fed and the ECB. Figures 1 and 2 compare headline and core inflation, respectively. As can be seen, the crisis and subsequent recession put disinflationary pressure in the two economies. It may be recalled that both of these central banks have an inflation objective close to two percent, using the PCE index for the Fed and the HICP for the ECB. Core inflation stayed below the inflation objectives of these two central banks. Conventional easing proved insufficient and additional unconventional easing became necessary. Figure 3 compares overnight rates in the US and euro area while Figure 4 compares the size of the balance sheets of the Fed and the ECB. Before the

\footnotetext{
${ }^{5}$ See Clouse et al (2003) for a review of unconventional policy easing options at the zero lower bound. In addition to QE, these options include alternative ways to increase the central bank balance sheet as well as exchange rate and communication policies that influence expectations of future policy actions. Durre and Pill (2012) provide a review of central bank balance sheet policies in Europe. It should be noted that the zero lower bound is not a hard constraint exactly at zero. The constraint is due to the existence of currency notes that earn a nominal zero return. Central banks can engineer slightly negative rates but some may also opt to stop cutting rates somewhat above zero. The reference to the zero lower bound is about the "effective" bound chosen by a central bank depending on the specific institutional setting and tradeoffs it may face. This need not be fixed as a central bank may adjust its "effective" lower bound with experience. During the crisis the ECB initially stopped at slightly positive rates but subsequently reconsidered its bound and moved to slightly negative rates.

${ }^{6}$ Clouse et al (2003) and Orphanides (2003) provide historical references.
} 
crisis, movements in the overnight rate captured changes in monetary policy, while the balance sheets of the two central banks were nearly flat. By contrast, since the crisis, while rates have been close to zero for both central banks, the size of their balance sheets changed dramatically. Although balance sheet increases have an accommodating role that is not reflected in overnight rates, this accommodation may be seen in longer rates that are not constrained by the zero lower bound. Figure 5 highlights this by showing the yields on ten-year government bonds for the US and Germany.

\section{III.2 Fiscal operations during the crisis}

In some respects, central bank balance sheet policies may be effectively equivalent to fiscal operations. First, at the zero lower bound, money is nearly equivalent to short-term government paper. Liquidity can be injected in the economy with the Treasury issuing additional zerointerest-rate bills or the central bank raising the quantity of high-powered money, also earning zero interest. At the zero lower bound, high-powered money and treasury bills are near perfect substitutes so these two policies may be indistinguishable from each other. By necessity, monetary and fiscal policies become much more closely linked at the zero lower bound than during periods when interest rates are clearly above zero.

Second, bailout operations aiming to restore the health of the financial sector are effectively fiscal operations. Provision of credit by the central bank to some private or government-related entities may sustain entities that would have otherwise collapsed. Central bank bailout operations are equivalent to the provision of fiscal support to troubled entities by the government. $^{7}$

A major issue with fiscal operations is that they have potentially large distributional effects. Such effects may be unavoidable during a crisis but this does not reduce the scope for potential controversy associated with them.

During the global financial crisis, central banks provided preferential support to some entities but not to others. Balance sheet policies had (and continue to have) immense distributional effects. This can raise questions when the central banks involved appear to provide preferential support on the basis of discretionary decisions or tailor-made "rules" adopted and adjusted during the crisis, rather than on the basis of principles and rules that are clear ahead of time- -before the identity of the beneficiary becomes known.

\footnotetext{
${ }^{7}$ Such operations are often undertaken by central banks in their role as lender of last resort which need not necessarily have a fiscal component. When emergency lending is provided at a "high rate” against "good collateral,” that is strictly in accordance to Bagehot's (1873) principles, it does not involve a fiscal transfer. Bailout operations with a fiscal component invariably violate some aspect of Bagehot's principles.
} 
The power to engage in distributional policies was not the intended purpose of central banks independence. The purpose was to protect price stability over time. In democracies, distributional matters should fall squarely in the domain of elected governments. Unfortunately, a number of the fiscal operations implemented during the crisis appear to fall in the category that raises questions. Indeed, some distributional effects arising from central bank discretionary decisions during the crisis appear to have had no clear basis on rules that were in place before the crisis, which raises serious governance questions about the operation of independent central banks.

The next two sections review some specific examples of policy decisions that raise questions for the Fed and ECB.

\section{Distributional issues: Federal Reserve}

As already mentioned, a central bank can enlarge its balance sheet by purchasing assets to provide unconventional monetary policy accommodation when this is needed for the aggregate economy. But the choice of what to purchase can provide preferential treatment to specific sectors of the economy over others. The Fed traditionally attempted to stay clear of such preferential treatment by doing all its monetary policy operations with US government bills and bonds. Plain QE could have been pursued during the crisis when the zero lower bound was reached and the Fed determined that additional accommodation was still needed. As part of its toolkit of unconventional monetary policy easing, however, the Fed decided to engage in additional asset purchases. Specifically, it decided to purchase large quantities of housingrelated mortgage backed debt (MBS). ${ }^{8}$ As Figure 6 shows, MBS holdings became a very important part of the Fed's balance sheet. The policy could be defended by noting that the housing sector had been disproportionately hurt by the crisis. Boosting the housing sector would help the economy overall. This may be true but it does not change the fact that the Fed's decision to buy MBS rather than just implement QE through purchases of long-dated government debt was equivalent to a massive subsidy to the housing sector over other sectors of the economy and that it disproportionately benefited holders of mortgage-backed securities over holders of other financial assets. This may have been effective as monetary policy, but this is a separate issue. The question raised is more fundamental: Whether it is the proper function of an independent central bank in a democratic society to use its discretion and decide which sectors of the economy deserve the support of its balance sheet and which don't.

It is interesting to note that, compared to other central banks, the Fed has rather limited authority on how to use its balance sheet for asset purchases. Congress has placed limits on the Fed which

\footnotetext{
${ }^{8}$ Goodfriend (2011) discusses fiscal aspect of Fed actions during the crisis. He describes operations such as MBS purchases as credit policy, which he argues should be seen as debt-financed fiscal policy.
} 
can purchase only US government and US government-guaranteed assets. The authority to purchase MBS resulted from 1960s legislation by Congress that was meant to encourage the Fed to buy government-guaranteed debt, in an effort to advance financing of pet projects. The political dimension of the problem is unmistakable. Why face contentious discussion over the budget in Congress, if the Fed could quietly achieve the same fiscal objective? An interesting example of this authority, as revisited in Haltom and Sharp (2014), was the financing of the construction of the Metro system in Washington, D.C. The Washington Metropolitan Area Transit Authority (WMATA) was established in 1967 for that purpose and issued debt to fund construction of the Metro system. By purchasing that debt, the Fed ended up financing the project, thereby vastly improving the efficiency of commuting in Washington, D.C. for residents of the metropolitan area which included Congressional staff as well as the staff of the Federal Reserve Board.

This is not to say that investment in the Washington metro in the 1970s or support of the US housing market in the 2010s was not a worthwhile cause. The question simply is whether it is appropriate for an independent central bank, rather than the fiscal authority of a democratic state, to use its discretionary authority to decide what is worthwhile to support and what is not. Once it got freed from the politicization it faced during the 1960s, and until the crisis-a period spanning decades - the Fed had provided an answer to this question: The Fed decided not to use its discretionary authority to finance pet projects or favor specific sectors of the economy.

An even more controversial aspect of balance sheet operations pertains to bailout operations that may suggest preferential treatment to specific private interests. As any central bank, the Federal Reserve has the authority to serve as a lender of last resort-provide loans backed by collateral to private entities under stress. In the case of the Fed, this authority was not limited to banks or even financial institutions. Under Article 13(3) of the Federal Reserve Act, the Board of Governors had the power to provide credit to virtually anyone, as long as it judged that conditions were unusual and exigent. As Meltzer (2013) points out, however, the Fed never announced a lender-of-last-resort policy and during the crisis acted in a manner that shifted bailout costs to taxpayers - an outcome stemming from the too-big-to-fail doctrine.

It is very difficult to judge crisis decisions after the fact. To the extent decisions follow clear principles and reflect the information available at the time as best as possible, even decisions that prove problematic after the fact could be justified and proper. A fundamental difficulty with ex post evaluation of crisis decisions is that counterfactuals may be hard to construct. Debates such as the differential treatment of Bear Stearns and Lehman during 2008 cannot be authoritatively settled since the relevant counterfactuals are not available. ${ }^{9}$

\footnotetext{
${ }^{9}$ Reinhart (2011) provides a thoughtful analysis of the dynamic inconsistency problems in the Bear-Lehman episode.
} 
Internal consistency and uniformity of different support decisions can be evaluated with greater confidence. Conditional on the decision to provide lending to too-big-to-fail institutions, for example, additional questions pertain to the terms of the lending arrangement. Is it legitimate for the central bank to use its discretionary power to decide on a case-by-case basis whether a specific firm will be allowed to secure financing at favorable terms while another firm would not be allowed similar terms?

An interesting case for the Fed relates to its treatment of non-bank financial institutions under stress. We may call this the Goldman vs A.I.G. comparison. ${ }^{10}$ Before the crisis, both Goldman and A.I.G. were non-bank financial corporations, not eligible for the usual discount window operations that Federal Reserve member banks have access to. In both cases, the Fed used its discretionary powers to provide lending. However, the lending was not provided on the same terms, nor could the difference in terms be explained on the basis of some rule or framework that had been developed before the crisis. In one case, the Fed protected the owners of the private entity by providing inexpensive credit. In the other case, some have argued, Fed actions effectively destroyed the value of the owners' stakes in the private entity. In both cases the institutions were bailed out but the distributional consequences for stakeholders were vastly different.

A.I.G. stakeholders filed a lawsuit against the Federal Reserve. As a result, in this case information from legal rulings has become available for some of the pertinent issues. A recent legal ruling determined that the Federal Reserve acted inappropriately (Kessler, 2015). Specifically, Judge Thomas C. Wheeler ruled that:

“The Government’s unduly harsh treatment of A.I.G. in comparison to other institutions seemingly was misguided and had no legitimate purpose, even considering concerns about 'moral hazard'."

Effectively, the ruling suggested that the Fed erred in discriminating against the interests of A.I.G. stakeholders. To reiterate, the issue at hand is not the treatment of either A.I.G or Goldman in isolation. The issue is whether Fed decisions exhibited reasonable uniformity and consistency. Ultimately some protection of equal treatment of the stakeholders of both Goldman and A.I.G. could have been expected. Inexpensive credit could have been provided to neither or to both with similar terms. The owners could have been protected or forced to lose their stakes in the companies in both cases or in neither case. The troubling question in this case is whether it is appropriate for an independent central bank in a democratic society to use its discretionary authority to decide which stakeholders of which private entity to wipe out and which to support. Does an independent central bank like the Fed have the legitimacy to discriminate in favor of

\footnotetext{
${ }^{10}$ For this comparison, “Goldman" simply serves as a representative of the numerous entities that were generously supported by the Fed with similar favorable terms that were not made available to A.I.G.
} 
Goldman and against A.I.G.? Should such discretionary authority be available to an independent central bank in a democracy? Don't such decisions fall squarely under the purview of elected governments?

\section{Distributional issues: ECB}

As difficult as the choices discussed for the Fed in the previous section may have been, the ECB has been facing far more difficult choices associated with the distributional consequences of its balance sheet policies. The ECB faces unique challenges as it was created to serve as the central bank for the euro area as a whole, which consists of the economies of all member states of the euro area but has no fiscal counterpart in the euro area. The ECB is also unique in that it is effectively unaccountable to any government and has immense discretionary powers, far greater than those of the Federal Reserve, powers that could be used well or be abused. Gaps in the design of the euro area, including gaps that were well understood before the introduction of the euro have put the ECB in an impossible position during the euro area crisis. ${ }^{11}$

The lack of a corresponding fiscal authority presents a challenge for the ECB, and especially for the operations that entail taking unusual risks on its balance sheet, as would have been expected to be encountered during the crisis. Should such risks be managed in a discretionary manner, on a case-by-case basis, depending on which member state benefits and which is harmed? The ECB can easily take decisions to favor specific member states over other member states in the euro area, or specific sectors and institutions in a specific member state over sectors and institutions in other member states. These powers stem from the European Union Treaty which cannot be corrected without unanimous consent of all EU member states. The ECB problem is therefore far more serious than any issues that might arise with the Federal Reserve. If any euro area government manages to exert undue influence at the ECB it may advance its own interests to the detriment of interests of other euro area member states through the common central bank and without obvious mechanisms for correction.

It goes without saying that the euro area crisis has been a nightmare for the ECB. As is well known, euro area governments have taken a series of decisions after the global financial crisis started that have created an existential crisis for the euro area. Questions persist as to whether the euro will survive or whether some member states will be forced by other member states to abandon it. The ECB has a clear primary mandate-price stability, and subject to that to provide support to the objectives of the European Union, as specified in the Treaty. But in light of the existential concerns about the euro, should the ECB be expected to focus on its primary mandate or to crisis management? If there is a conflict in these two, should the ECB respect its mandate

\footnotetext{
${ }^{11}$ See Sims $(1999,2012)$ for a discussion of institutional problems facing the ECB due to the absence of a fiscal counterpart.
} 
or should it yield to politics whenever the existence of the euro comes under threat? Should tradeoffs regarding the survival of the euro be ignored or dominate decisions, including decisions regarding monetary policy aiming to attain price stability for the euro area?

Views on these questions can reasonably vary. One view is that dedication to the mandate is appropriate. Another view holds that preserving the euro area could be more important, even if this means politicizing the ECB in a manner incompatible with the Treaty. A review of ECB decisions during the crisis suggests that the ECB did not escape being immersed in decisions with horrendous distributional effects across euro area member states, distributional effects that were clearly not envisaged when the ECB was given virtually unchecked discretionary powers. ${ }^{12}$

Numerous dimensions can be examined to see the differences in how various member states have been treated by the ECB during the crisis. Questions can be raised regarding the effectiveness of unconventional monetary policy and crisis response measures across member states. The ECB serves as the central bank for all member states of the euro area so an obvious question is whether support has been similarly beneficial across member states. Put differently, has the ECB ensured equal treatment across different member states?

One relevant dimension relating to the effectiveness of unconventional monetary policy is the support the ECB provided to government debt markets. Another dimension regards support of the banking sectors across member states. It could be argued that on both fronts ECB support to different member states has been decidedly uneven during the crisis.

Consider the uneven effectiveness of unconventional monetary policy. This has been very problematic, with some member states experiencing tightening of monetary conditions during the crisis, exactly when the ECB would have been expected to provide easier monetary policy instead. The result has been a monetary policy that contributed to deep recessions in some member states, while other member states enjoyed near-ideal monetary conditions. ${ }^{13}$

Figure 7 compares the yields on ten-year government bonds in two of the largest member states, Germany and Spain. As mentioned earlier, ECB unconventional monetary policy reduced the yields of German government bonds in a manner similar to the reduction of US government bond yields engineered by the Fed. This benefited Germany tremendously but was not reflected in monetary conditions faced by some other countries. Although sharing the same currency,

\footnotetext{
${ }^{12}$ In may appear paradoxical how a "rules-based institution," such as the ECB would like to be, enjoys virtually unchecked discretion. This simply reflects the power the ECB has to set its own operational rules and the discretion to adjust them or selectively waive them.

${ }^{13}$ Obviously, the horrendous outcomes in the euro area are not primarily the result of ECB policies but of the political dynamics of the member states and the flawed design of the euro area. Eichengreen (2015), Kopits (2015), Orphanides (2015), Wolf (2014) and Wyplosz (2014) offer expositions of various dimensions of the broader problem.
} 
monetary conditions in Spain have been considerably tighter than those in Germany in the past several years. This reflects a number of factors, including decisions by euro area governments. However, the wide gap in the cost of financing between Germany and Spain that developed during the crisis is not unrelated to ECB decisions. As explained by De Grauwe (2011) and Buiter and Rabhari (2012), the deterioration observed in 2010 and 2011 related to the unclear role of the ECB in government bond markets — specifically the extent to which the ECB was willing and/or able to appear as a lender of last resort to member state governments in a manner similar to the role the Bank of England could serve for the U.K. government. ${ }^{14}$ This largely depended on ECB discretionary decisions. ${ }^{15}$ Similarly, the partial convergence of monetary conditions observed since Summer 2012, could be largely attributed to the ECB's discretionary decisions relating to the outright monetary transactions (OMT) program. ${ }^{16}$

The difference in the relative stance of monetary policy has had important consequences for the different economic outcomes observed across euro area member states since the beginning of the euro area crisis. Figure 8 presents a comparison of real GDP per person in Germany and Spain, superimposing also the United States as a benchmark for comparison. As can be seen, the relatively tight monetary policy conditions in Spain and relatively easy conditions in Germany have been associated with a notably better economic performance in Germany relative to that in Spain.

Once again, it is important to recognize that some distributional effects across sectors or states may be the unavoidable consequence of policy decisions made for the common good on the basis of a pre-determined framework and rules. However, an issue arises when the distributional effects are not the result of applying a clear framework decided before the crisis, but rather the outcome of discretionary decisions that may be tailor-made to favor some sectors/states and discriminate against other sector/states.

In the case of the euro area, a troubling aspect of the crisis has been that the distribution of potential benefits and losses appears to have become an unduly important factor in discretionary decision making, with little regard to the principle of equal treatment one would have expected to prevail in a democratic society. ${ }^{17}$

Returning to the comparison of the ECB and the Federal Reserve, it is quite clear from Figure 4 that from mid-2012 to the end of 2014 the ECB pursued a contractionary monetary policyshrinking its balance sheet-while the Fed pursued an expansionary policy. From Figure 2,

\footnotetext{
14 The comparison with the Bank of England is particularly useful because the U.K. is a member state of the European Union. The mandate and legal framework of the Bank of England, including importantly a prohibition of monetary financing, is similar to that of the ECB, in accordance to the European Union Treaty.

${ }^{15}$ See also Gros (2012) and Kopf (2011) for pertinent discussions of this period.

${ }^{16}$ Pill and Reichlin (2014) provide a detailed discussion of the OMT and its effects on government bond markets.

17 See Orphanides (2014b,c) for examples of specific decisions that raise these questions.
} 
which compares core inflation in the two economies, we can see that as a result of its tight policies, core inflation in the euro area has been systematically below the ECB's objective. In contrast, the Fed has achieved a better outcome. The difference could not be attributed to unforeseen developments or mere forecast errors as the tightness of ECB policy over this period was evident in real time. ${ }^{18}$ During the course of 2014, while the ECB was reducing the size of its balance sheet, it was also revising downwards its inflation forecasts. For example, the forecast of 2016 inflation declined from 1.5\% in March 2014 to 1.3\% in December 2014, notably below the ECB's definition of price stability.

A question that arises is what arguments could possibly justify the ECB's inappropriately tight policy over this period. What is the mandate of the ECB? One might have thought that the mandate of the ECB was already clear: to maintain monetary conditions that are appropriate for the euro area as a whole and, subject to that contribute to the other noble objectives of the EU Treaty. And yet, in December 2014, when the ECB reluctantly decided to consider reversing its inappropriately tight policy stance, a member of the ECB Governing Council who is also a state official for a euro area member state reportedly opposed the decision, noting: "We have a monetary policy that is too expansive for Germany" and furthermore: "Extremely low interest rates caused countries' willingness to implement structural reforms to tail off." (Carrel, O'Donnell and Martin, 2014).

This raises numerous questions about ECB monetary policy. Did the ECB maintain an inappropriately tight monetary policy for the euro area because changing course would have been inconvenient for a specific member state? Did the ECB maintain an inappropriate policy for the euro area as a whole in order to push the elected governments of some member states to implement structural reforms that some other member state thought should have been implemented? More generally, under what conditions, if any, is it legitimate for the ECB to implement monetary policy with undue influence from one member state, when in so doing it fails to achieve its primary mandate of ensuring that inflation in the euro area is close to two percent?

It is also of interest to note that even when it embarked on a form of QE in 2015, the ECB used its discretion to deviate from its established principle of loss sharing in a very significant manner, with important distributional consequences. The issue regards the pooling of risks in the common monetary policy of the ECB. The principle established when the ECB started operating (well before the crisis) was that risks pertaining to monetary policy operations in the euro area would be shared. Potential profits and losses would be shared proportionately, according to capital key of the National Central Banks (NCB) of the member states. During the crisis, when the ECB decided in 2010 to embark on purchases of government debt for selected member states

\footnotetext{
${ }^{18}$ See Ubide (2014) and Orphanides (2014d).
} 
as part of its Securities Market Programme (SMP), risks were pooled, as usual. ${ }^{19}$ However, purchases of government debt by the ECB proved controversial in Germany and the ECB was subjected to multiple lawsuits, possibly influencing subsequent decisions.

In taking the decision to embark on QE, the ECB decided that rather than pool risks, purchases of government debt should be segmented across national borders inside the euro area. Each NCB would be purchasing debt of its own government separately and be responsible for any profits and losses from those purchases. The ECB would also purchase some non-government bonds for which risks would be pooled, to give the appearance of partial risk sharing for the overall decision. The account of the January 2015 meeting reveals arguments in the discussion:

"Members discussed the appropriate modalities of risk sharing related to the purchases of securities issued by euro area governments and agencies and European institutions. On the one hand, arguments were made in favour of full risk sharing so as to counter perceptions of a lack of unity. Full risk sharing would also underline the singleness of monetary policy. On the other hand, in view of concerns about moral hazard it was argued that a regime of partial loss sharing would be more commensurate with the current architecture of Economic and Monetary Union and the Treaties under which the ECB operates.” (ECB, 2015.)

The decision suggests that even though it was acknowledged that the normal loss-sharing regime was more consistent with the single monetary policy, concerns about "moral hazard" dominated. The account failed to clarify what these concerns were, but the reference was probably to potential actions of euro area governments. To the extent the moral hazard fears that caused the ECB to deviate from normal loss-sharing procedures did indeed refer to elected governments, it would have been of interest to also provide some explanation as to the legitimacy of the ECB taking upon itself the responsibility of “protecting” the euro area from moral-hazard-induced actions by the democratically elected governments.

Understanding this decision outside the broader political tensions of the euro area is impossible. Even though the euro was supposed to be irrevocable, it is common knowledge that not all government officials in all member states respect this commitment and that some want to maintain the option to threaten other member states with exit from the common currency. Maintaining the possibility that some member states will potentially exit the currency union has tremendous distributional effects that benefit those member states that are perceived as relatively stronger, e.g. Germany, and harm member states perceived as weaker, e.g. Spain. Indeed, this is

\footnotetext{
${ }^{19}$ The SMP was initiated in May 2010. It entailed purchases of government debt of Italy, Spain, Portugal, Ireland and Greece with the stated aim to restore an appropriate monetary policy transmission mechanism in member states under stress.
} 
a key determinant of the relative financing costs of the respective governments. ${ }^{20}$ As an independent institution, the ECB could have decided to pursue the best monetary policy for the euro area as a whole, taking for granted the irreversibility of the euro and the responsibility of the governments to maintain it, at least until the governments specifically changed the prevailing framework. Had the ECB acted in this manner, spreads of euro area governments would have been compressed as the leverage of any government to use the threat of euro exit against other governments would be lower.

In the event, with its QE decision, the ECB signaled that it wished to account for the possibility of states leaving the euro area and protect its balance sheet against such eventualities. With the procedure adopted, when a member state leaves the euro area, the ECB would be fully protected from the possible loss on its balance sheet in case the exchange rate of the exiting country weakens. With its decision the ECB opted to reinforce spreads among government debt of different member states. Effectively the ECB used its discretionary power to introduce an implicit tax on member states perceived as weak and a subsidy on member states perceived as strong. Needless to say, this decision reinforces a dynamic that raises the odds that a member state will be forced to leave the currency area, hardly consistent with the ECB's mandate.

Questions regarding the distributional consequences of ECB decisions during the crisis are not limited to monetary policy. More controversial have been decisions relating to the management of the euro area crisis, when ECB interventions provided the appearance that it was aligned with the political objectives of specific member state governments against the political objectives of other member states. The design of the euro area effectively gives the ECB complete discretion on maintaining monetary stability or allowing a panic to materialize in each one of the member states that have joined the euro. Among others, the ECB has the discretion to decide the conditions the ECB believes are appropriate to declare that government debt, issued by a member state, should not be considered trustworthy and would not qualify as collateral for monetary policy operations in the euro area. The ECB also interprets its powers to include the discretionary authority to terminate lender-of-last-resort operations in any state whose government is considered untrustworthy, or any state that refuses to implement specific conditions that are promoted by some other member state.

One could question whether the intent of the writers of the European Union Treaty was to give such immense discretionary powers with little if any accountability to a body of unelected officials. The fact remains that the ECB not only has such powers but, to the surprise of many, has exercised these discretionary powers in a manner that has raised questions during the crisis. As an illustration, it suffices to revisit one example: The February 2015 decision to suspend the eligibility of Greek government debt as ECB collateral (ECB, 2015a). This decision was taken

\footnotetext{
${ }^{20}$ Broyer, Petersen and Schneider (2012) and Dany et al (2015) present calculations of the monetary benefit accruing to Germany from the crisis.
} 
shortly after a new left-wing government was elected in Greece and in the middle of political negotiations on an IMF/EU program. The decision, which was widely seen as supporting the political interests of certain elected euro area governments against the elected Greek government, was heavily criticized by outside observers. For example, it prompted the Economist, to identify a new role for the ECB in the political discussions pertaining to the crisis: "The Enforcer." The subtitle of the article explained that it was about "How the European Central Bank can dictate terms to the Greek government” (Economist, 2015). In an editorial in the New York Times, Paul Krugman pondered whether the ECB would clarify its proper role or act as "Germany's debt collector.” (Krugman, 2015).

This was not the first time the ECB intervened in a manner that could be seen as decidedly political and one-sided (in the sense of promoting the interests of one member state over the interests of another member state) during the crisis. ${ }^{21}$ However it was the occasion that attracted wide attention, no doubt due to the unconventional, anti-establishment negotiating positions professed by the newly elected Greek government. In this case it could be argued that the newly elected Greek government was provocative and misguided. Perhaps someone in the euro area had to make an intervention of some sort. A possible defense for any politically-motivated decision taken by a central bank is that it may aim to serve the "common good." In the case of the euro area, given the unparalleled discretion and lack of accountability that is enjoyed by the ECB, many decisions could be potentially justified as allowable within the context of the EU Treaty. This begs the question: Is it legitimate for the ECB to use its discretionary power to decide on a case-by-case basis which elected government of which member state should be "cut down to size" for the benefit of other member states and perhaps what the ECB views as the "common" good? Is this compatible with our understanding of democracy in Europe?

In summary, the ECB proved to be an effective central bank during the crisis but only for some member states of the euro area. Use of its balance sheet had immense distributional consequences. For some member states, ECB actions reflected both the crisis response and unconventional monetary policy measures expected from the central bank of any economy. For other member states, ECB actions reflected neither the crisis response nor the unconventional policy measures expected from a country's central bank.

These outcomes were not pre-ordained by rules that had been agreed when the euro area was created. They were the outcome of discretionary decisions during the crisis. These decisions included numerous aspects that ordinarily would be seen as technical issues such as determination of collateral eligibility, asset purchases, provision of emergency liquidity assistance, loss-sharing arrangements etc. In many cases, it could be argued that alternative

\footnotetext{
${ }^{21}$ In a paper prepared for the European Parliament's Committee on Economic and Monetary Affairs, Whelan (2015) discusses the ECB's role in Greece in 2015 as well as its role in Ireland in 2010. Whelan identifies the ECB's "confused" lender-of-last-resort role as a reason why the ECB may appear to be overly involved in political developments and potentially act beyond its legal mandate.
} 
discretionary decisions could have ensured more equal treatment for member states. However the ECB had the discretionary power to change the rules as it saw fit during the crisis, with the result of benefiting some member states and discriminating against others. Despite their fiscal consequences and highly unequal distributional consequences, most of the decisions taken were likely within the legal powers of the ECB, given the immense discretion that is granted to the ECB by the EU Treaty. Is such discretionary authority compatible with the democratic principles of Europe? Should any unelected and unaccountable institution maintain such discretionary power?

\section{After the crisis}

Central bank actions in the aftermath of the global financial crisis have likely protected the global economy from the worst of possible outcomes that could have materialized. However, by becoming the "only game in town" and using their discretionary powers, central banks revealed the immense power of their balance sheet and the fact that during a crisis the fiscal implications of their actions are much greater than had been commonly understood.

Both in the case of the Federal Reserve and the ECB, discretionary authority was employed to implement fiscal operations with immense distributional consequences. These distributional aspects of central bank balance sheet policies raise troubling questions regarding the discretionary power granted to independent central banks, when the original intent of central bank independence was primarily to ensure the maintenance of price stability.

How should this be resolved going forward? In democratic societies, independent central banks do not have the legitimacy and should not have the authority to make discretionary decisions with immense distributional fiscal consequences, as has been observed during the crisis. It could be argued that actions taken by both the ECB and the Fed during the crisis overstepped the legitimacy of these institutions.

The main difficulty emanates from discretionary actions. While discretion can allow for good outcomes, when employed to tackle unforeseen complications in an efficient manner, it can also lead to disastrous results, leveraging specific interests to the detriment of others in a manner that is inconsistent with the functioning of democracy. If central bank independence is to be maintained going forward, strict rules and boundaries may need to replace current discretionary powers, as argued by Goodfriend (2014) and others. Unless the discretionary powers of central banks are curtailed and accountability is improved, it is hard to see how the fiscal and distributional consequences of central bank actions can be tolerated for long in our democracies. The alternative, as Goodhart (2010) suggests, would be that: "The idea of the Central Bank as an independent institution will be put aside.” 


\section{References}

Bagehot, Walter (1873), Lombard Street: A Description of the Money Market. H.S. King \& Co.

Broyer, Claudia, Ann-Katrin Petersen and Rolf Schneider (2012). Impact of the euro crisis on the German economy. Allianz working paper 154, September.

https://www.allianz.com/v_1349875733000/media/economic_research/publications/working_pa pers/en/euroimpact.pdf

Buiter, Willem (2014). Central Banks: Powerful, Political and Unaccountable? CEPR Discussion Paper No. 10223, October. http://ssrn.com/abstract=2526351

Buiter, Willem and Ebrahim Rahbari (2012). The European Central Bank as Lender of Last Resort for Sovereigns in the Eurozone. Journal of Common Market Studies 2012 Volume 50 Supplement, 6-35, September. http://onlinelibrary.wiley.com/doi/10.1111/j.1468$\underline{\text { 5965.2012.02275.x/abstract }}$

Carrel, Paul John O'Donnell and Michelle Martin (2014). ECB's Weidmann says monetary policy too expansive for Germany, Reuters, December 5. http://www.reuters.com/article/usbundesbank-weidmann-idUSKCNOJJ0V120141205

Clouse, James, Dale Henderson, Athanasios Orphanides, David Small and Peter Tinsley (2003). Monetary Policy When the Nominal Short-Term Interest Rate is Zero. Topics in Macroeconomics 3(1). http://dx.doi.org/10.2202/1534-5998.1088

Dany, Geraldine, Reint E. Gropp and Gregor von Schweinitz (2015). Germany’s Benefit from the Greek Crisis. IWH Online, 7/2015. http://www.iwh-halle.de/d/publik/iwhonline/io_201507.pdf

De Grauwe, Paul (2011). The Governance of a Fragile Eurozone. Revista de Economía Institucional, Vol. 13, No. 25, 13-41, July/December. (in Spanish). http://www.scielo.org.co/pdf/rei/v13n25/v13n25a02.pdf

Durre, Alain and Huw Pill (2012). Central Bank balance sheets as policy tools. In Are central bank balance sheets in Asia too large? BIS Papers No. 66.

https://www.bis.org/publ/bppdf/bispap66.htm

Economist (2015). The enforcer: How the European Central Bank can dictate terms to the Greek government, February 7. http://www.economist.com/news/finance-and-economics/21642210how-european-central-bank-can-dictate-terms-greek-government 
Eichengreen, Barry (2015). Hall of Mirrors: The Great Depression, the Great Recession, and the Uses_and Misuses_-of History. Oxford University Press.

European Central Bank (2015a). Eligibility of Greek bonds used as collateral in Eurosystem monetary policy operations. Press release, February 4.

https://www.ecb.europa.eu/press/pr/date/2015/html/pr150204.en.html

European Central Bank (2015b). Account of the monetary policy meeting of 21-22 January 2015. February 19. https://www.ecb.europa.eu/press/accounts/2015/html/mg150219.en.html

Fischer, Stanley, Ratna Sahay and CarlosVégh (2002). Modern hyper- and high inflations. Journal of Economic Literature, 40(3), 837-880, September.

http://dx.doi.org/10.1257/002205102760273805

Goodfriend, Marvin (2011). Central banking in the credit turmoil: An assessment of Federal Reserve practice. Journal of Monetary Economics 58(1) 1-12, January.

http://dx.doi.org/10.1016/j.jmoneco.2010.09.008

Goodfriend, Marvin (2014). Lessons from a century of FED policy: Why monetary and credit policies need rules and boundaries. Journal of Economic Dynamics and Control 49, December. http://dx.doi.org/10.1016/j.jedc.2014.09.005

Goodhart, Charles (2010). The Changing Role of Central Banks. BIS Working Paper 326, November. www.bis.org/publ/work326.pdf

Gros, Daniel (2012). On the Stability of Public Debt in a Monetary Union. Journal of Common Market Studies 2012 Volume 50 Supplement, 36-48, September.

http://onlinelibrary.wiley.com/doi/10.1111/j.1468-5965.2012.02273.x/abstract

Haltom, Renee, and Robert Sharp (2014). The First Time the Fed Bought GSE Debt. Federal Reserve Bank of Richmond Economic Brief, EB14-04, April.

https://www.richmondfed.org/publications/research/economic_brief/2014/eb_14-04

Hawkins, John (2003). Central bank balance sheets and fiscal operations, BIS Papers No. 20. http://www.bis.org/publ/bppdf/bispap20d.pdf

Kessler, Aaron (2015). Ex-A.I.G. Chief Wins Bailout Suit, but Gets No Damages. The New York Times. June 15. http://www.nytimes.com/2015/06/16/business/dealbook/judge-sides-withex-aig-chief-greenberg-against-us-but-awards-no-money.html 
Kopf, Christian (2011). Restoring Financial Stability in the Euro Area. CEPS Policy Brief 237, March. http://www.ceps.eu/book/restoring-financial-stability-euro-area

Kopits, George (2015). Managing the Euro Debt Crisis. Paper presented at the Conference on Rethinking Fiscal Policy after the Crisis in Bratislava, September.

Krugman, Paul (2015). A Game of Chicken. The New York Times, 6 February, p. 23. http://www.nytimes.com/2015/02/06/opinion/a-game-of-chicken.html

Meltzer, Alan (2013). What's Wrong with the Fed? What Would Restore Independence? CATO Journal. 33(3), Fall. http://www.cato.org/sites/cato.org/files/serials/files/catojournal/2013/9/cjv33n3-8.pdf

Orphanides, Athanasios (2013). Is Monetary Policy Overburdened? BIS Working Paper 435, December. http://www.bis.org/publ/work435.htm

Orphanides, Athanasios (2014a). The Need for a Price Stability Mandate. CATO Journal. 34(2), Spring/Summer.

http://object.cato.org/sites/cato.org/files/serials/files/cato-journal/2014/5/cato-journal-v34n24.pdf

Orphanides, Athanasios (2014b). The euro area crisis: Politics over economics. Atlantic Economic Journal 42(3), September. http://dx.doi.org/10.1007/s11293-014-9419-1

Orphanides, Athanasios (2014c). Are rules and boundaries sufficient to limit harmful central bank discretion? Lessons from Europe. Journal of Economic Dynamics and Control 49, December. http://dx.doi.org/10.1016/j.jedc.2014.09.008

Orphanides, Athanasios (2014d). ECB policy and Fed normalization. CEPR Policy Insight No. 74, November. http://cepr.org/sites/default/files/policy_insights/PolicyInsight75.pdf

Orphanides, Athanasios (2015). The euro area crisis five years after the original sin. Credit and Capital Markets, 48(4), 533-563, December. http://ejournals.dunckerhumblot.de/doi/abs/10.3790/ccm.48.4.535

Pill, Huw and Reichlin, Lucrezia (2014). Exceptional Policies for Exceptional Times: The ECB's Response to the Rolling Crises of the Euro Area, and How it Has Brought Us Towards a New Grand Bargain. CEPR Discussion Paper 10193, October. http://ssrn.com/abstract=2510050 
Reinhart, Vincent (2011). A Year of Living Dangerously: The Management of the Financial Crisis in 2008. Journal of Economic Perspectives, 25(1), Winter, 71-90.

https://www.aeaweb.org/articles?id=10.1257/jep.25.1.71

Ricardo, David (1824). Plan for the Establishment of a National Bank, reprinted in .R.McCulloch (ed) The Works of David Ricardo, London: John Murray, 1888.

http://oll.libertyfund.org/title/1395/83017

Sargent, Thomas. J., and Neil Wallace (1981). Some Unpleasant Monetarist Arithmetic. Quarterly Review of the Minneapolis Federal Reserve Bank, Fall, 1-17.

Sims, Christopher (1999). The precarious fiscal foundations of EMU. De Economist, 147(4), 415-436. http://www.princeton.edu/ sims/.

Sims, Christopher (2012). Gaps in the institutional structure of the euro area. Public Debt, Monetary Policy and Financial Stability, Financial Stability Review No. 16, Banque de France, April. https://www.banque-france.fr/uploads/tx_bdfgrandesdates/FSR16-20-04.pdf

Tucker, Paul (2015). The Pressing Need for More Complete Central Bank Policy Regimes. Paper presented at the BIS Research Conference in Lucerne on June 26, 2015.

Tucker, Paul (2016). The Political Economy of Central Bank Balance Sheet Paper. Paper presented at the Federal Reserve Bank of New York on May 4, 2016.

Ubide, Angel (2014). Is the European Central Bank Failing Its Price Stability Mandate? Peterson Institute for Economics Policy Brief No. 14-5, February. https://piie.com/publications/pb/pb14$\underline{\text { 5.pdf }}$

Whelan, Karl (2015). The ECB and Financial Assistance Programmes: Has ECB Acted Beyond its Mandate? Paper prepared for the session of the Monetary Dialogue, the Committee on Economic and Monetary Affairs (ECON) of the European Parliament, November 2015. https://polcms.secure.europarl.europa.eu/cmsdata/upload/bb7ffa74-62b1-4e00-92b5402bd3c19ad2/WHELAN_FINAL.pdf

Wolf, Martin (2014). The Shifts and the Shocks: What We've Learned-and Have Still to Learnfrom the Financial Crisis. Penguin Press.

Wyplosz, Charles (2014). The Eurozone crisis: A near-perfect case of mismanagement. Economia Marche Journal of Applied Economics, XXXIII(1): 1-13. http://economiamarche.univpm.it/index.php/em/article/view/38/35 
Figure 1

Fed vs ECB: Inflation

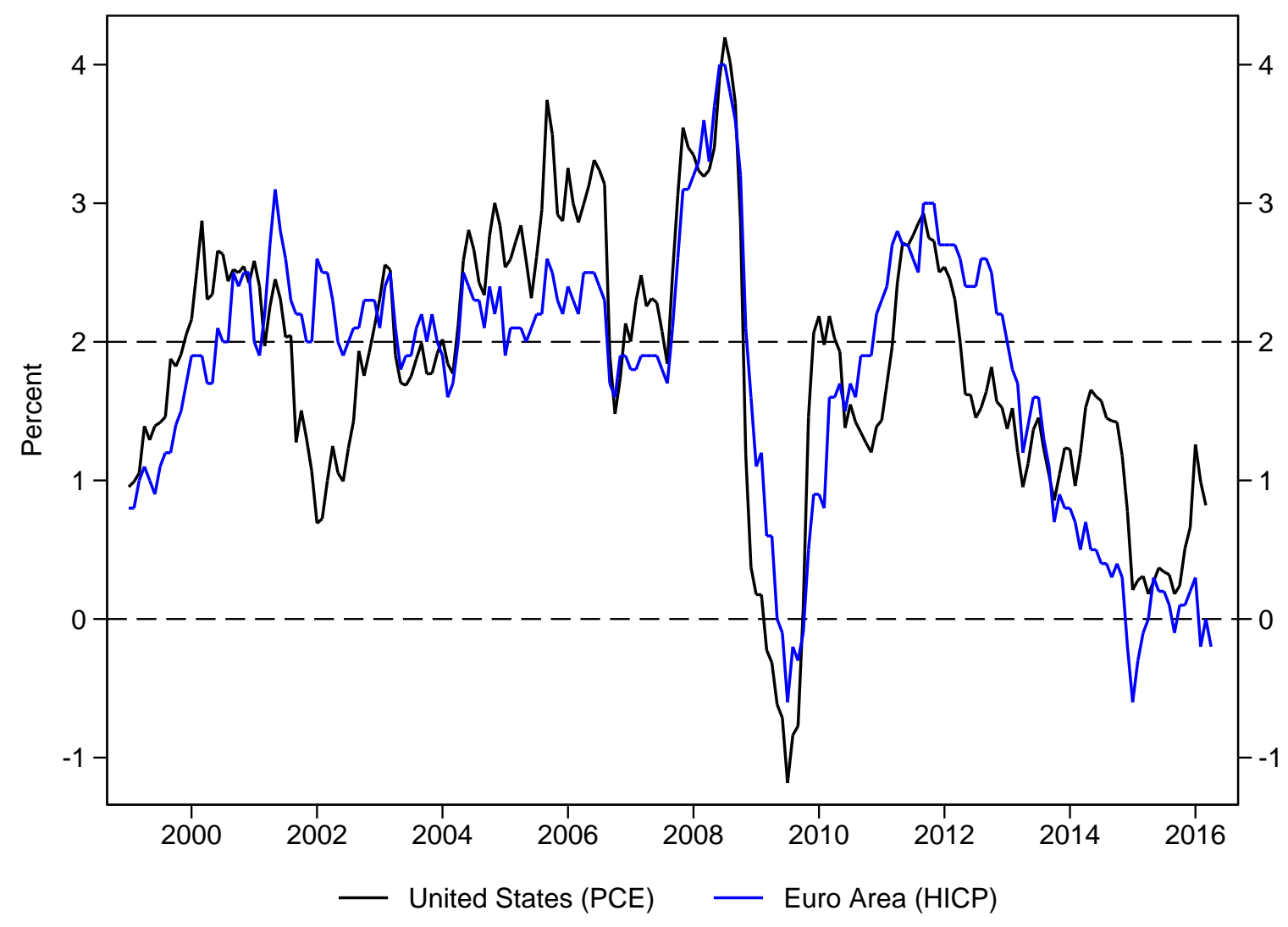

Notes: Headline PCE (for Federal Reserve) and HICP (for ECB). 
Figure 2

Fed vs ECB: Core Inflation

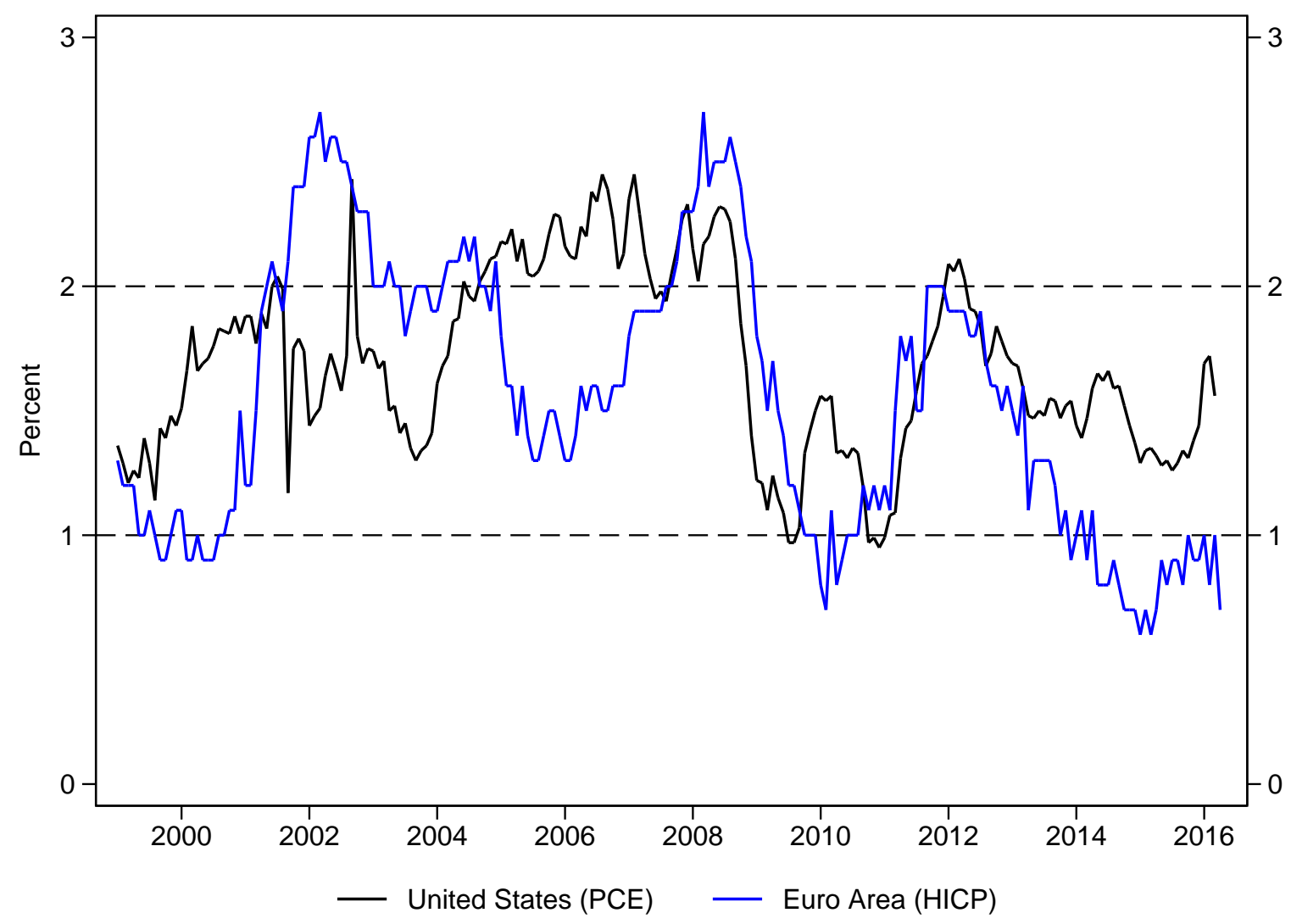

Notes: PCE excluding food and energy (for Federal Reserve) and HICP excluding energy and unprocesses food (for ECB). 
Figure 3

Fed vs ECB: Overnight interest rate

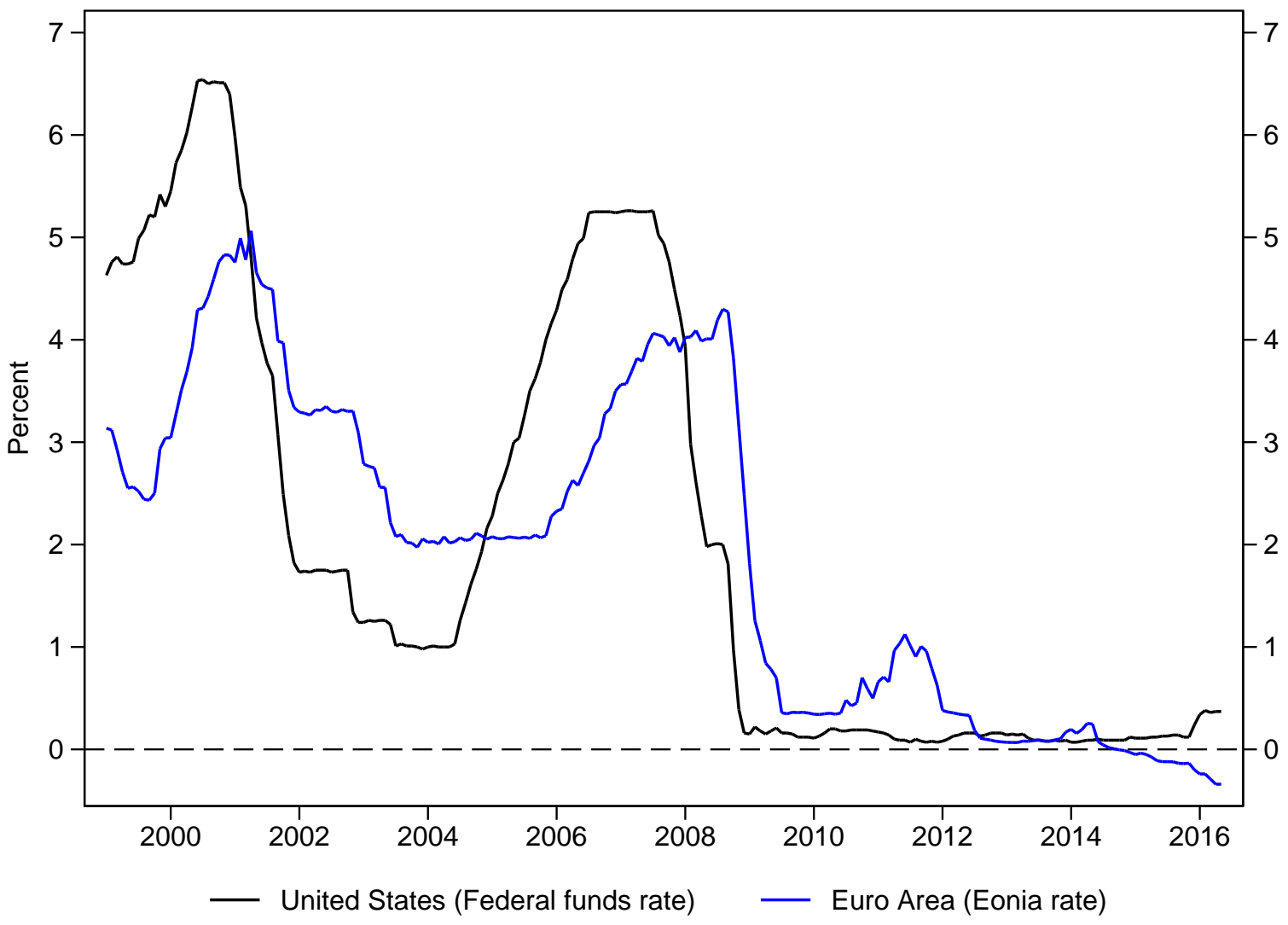

Notes: Federal funds (for Federal Reserve) and eonia (for ECB). 
Figure 4

Fed vs ECB: Balance sheet size

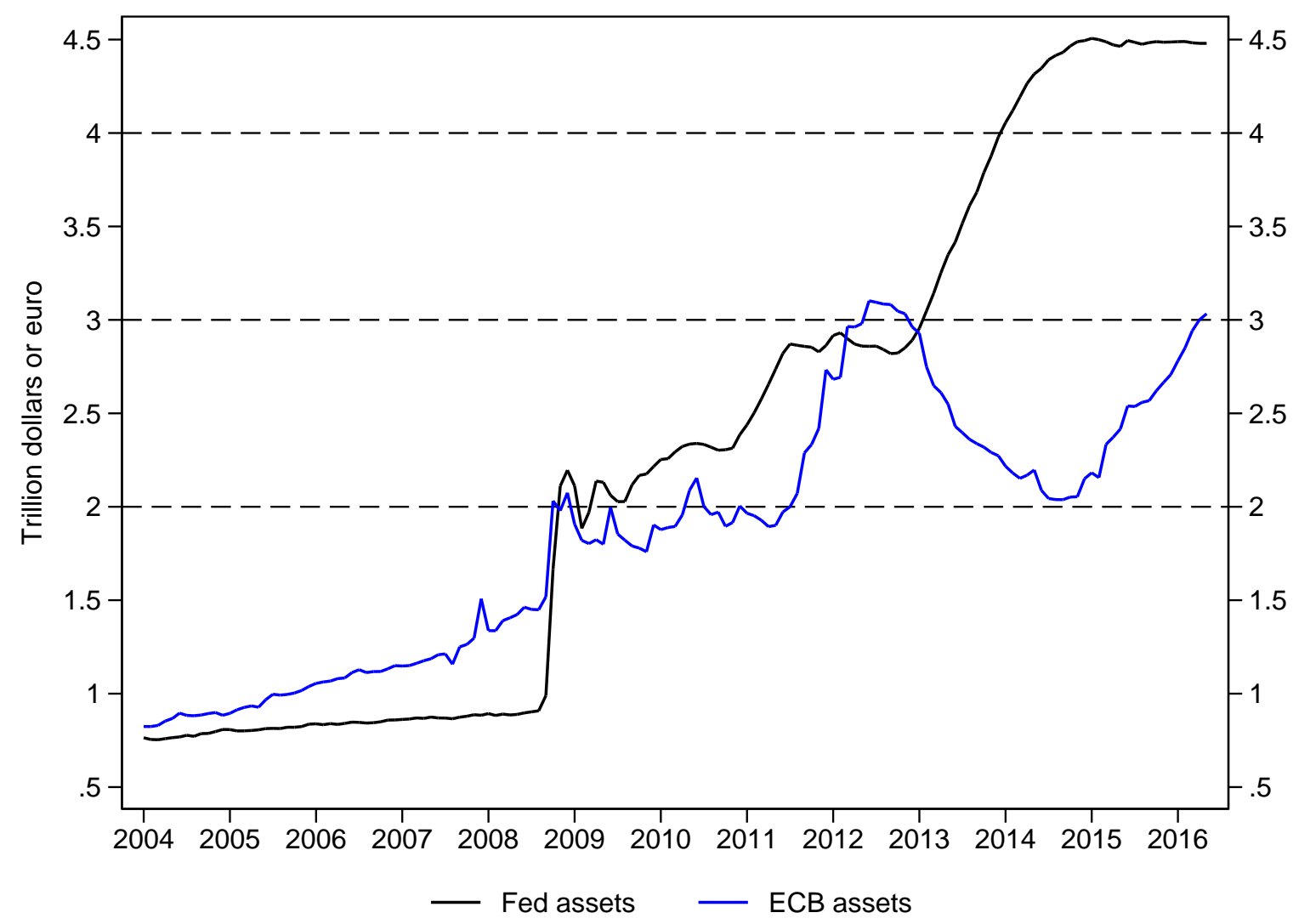

Notes: Trillion dollars (for Federal Reserve) and trillion euro (for ECB). 
Figure 5

Effectiveness of unconventional policy easing

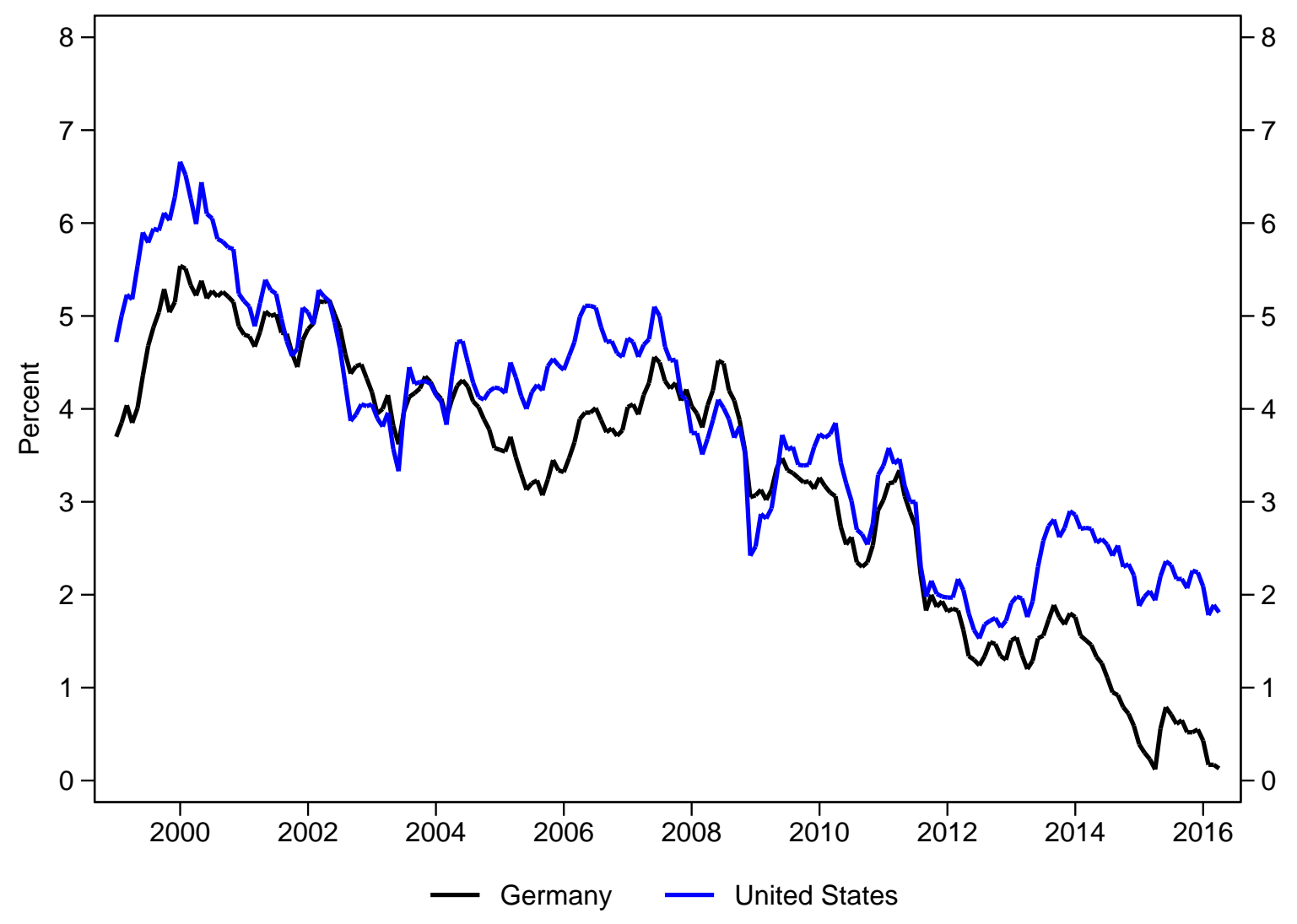

Notes: Yields of ten-year government bonds. 
Figure 6

The balance sheet of the Federal Reserve

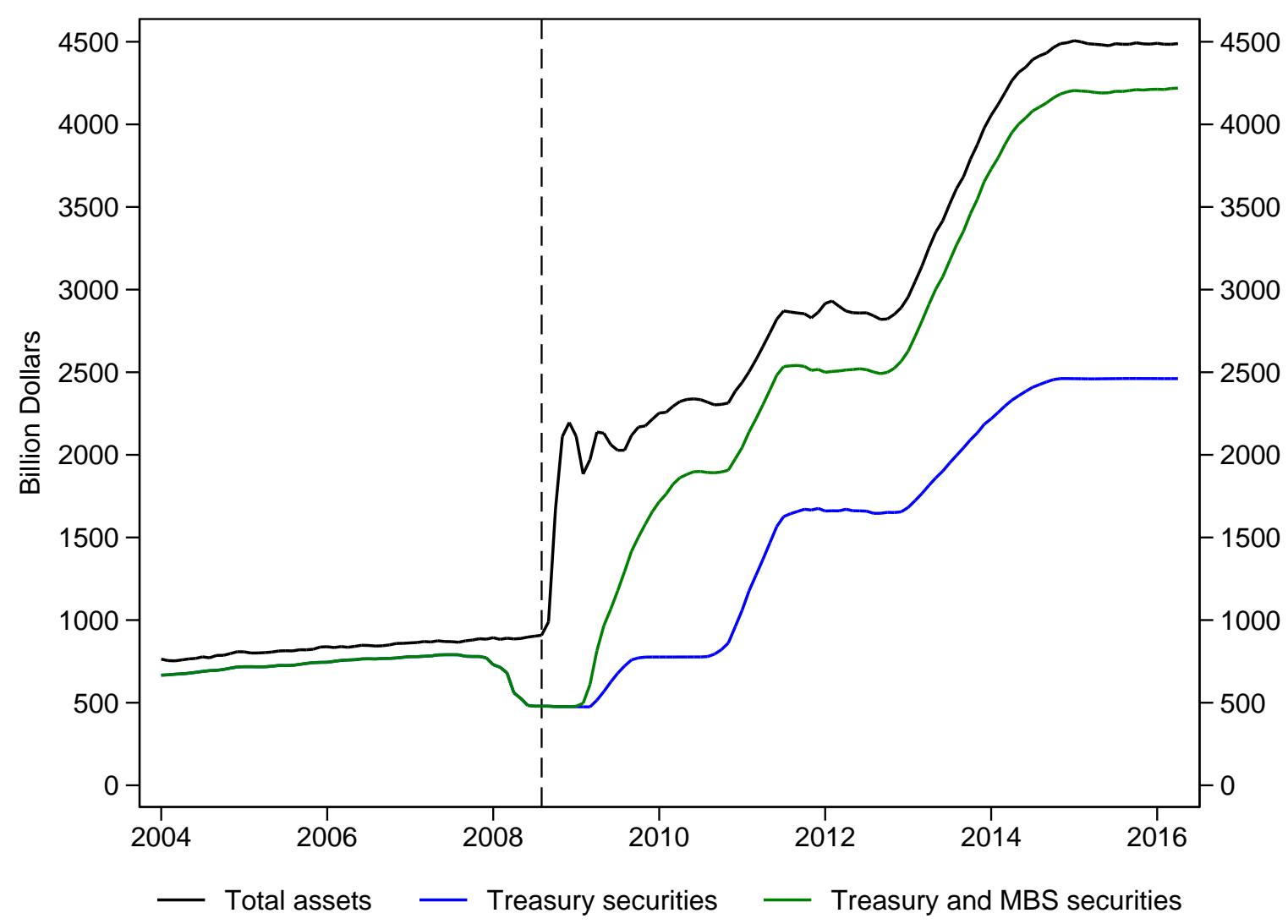

Notes: Decomposition of balance sheet into three categories of assets: Treasury securities, Mortgage Backed Securities and other. 
Figure 7

Effectiveness of unconventional policy easing

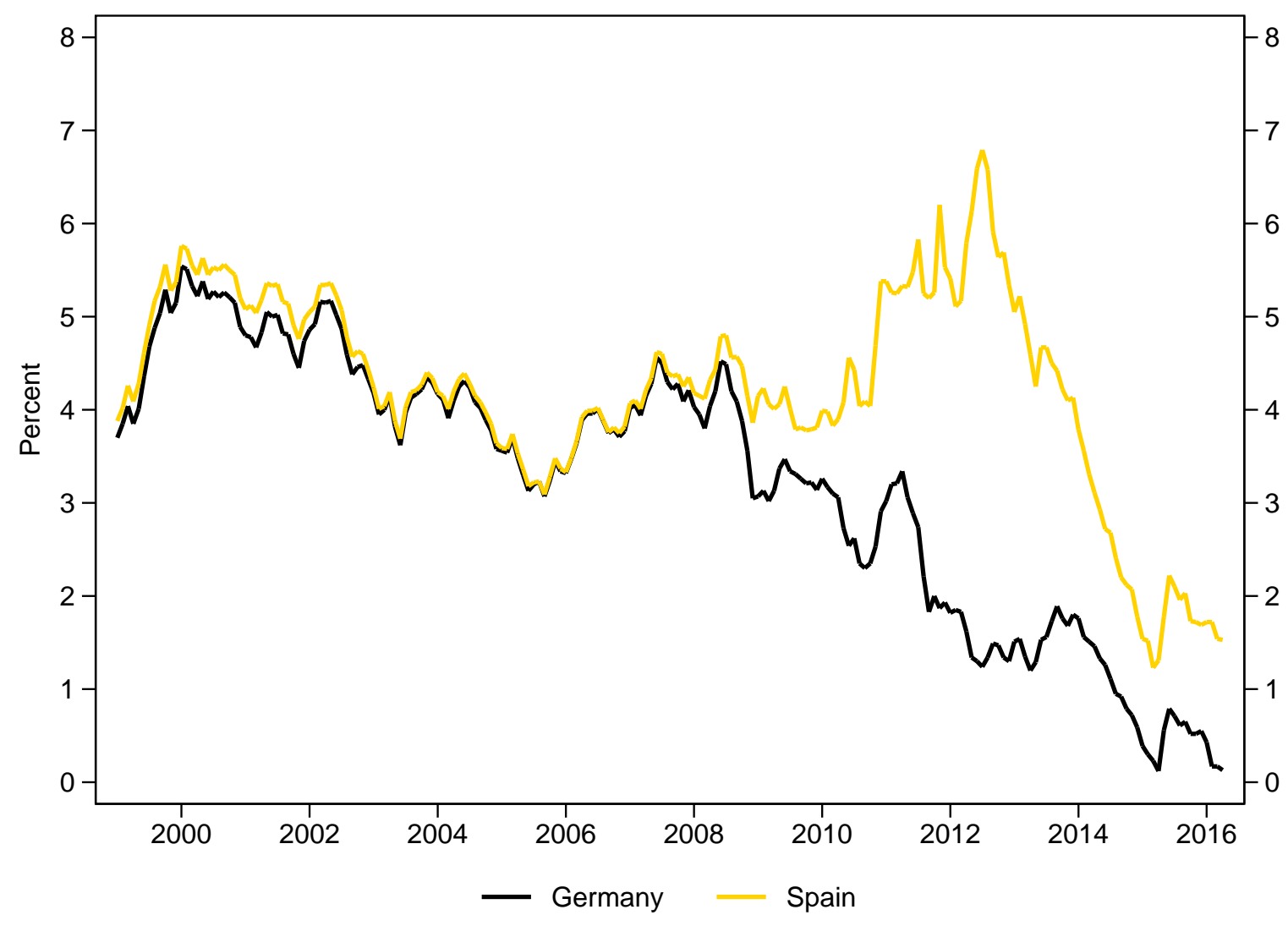

Notes: Yields of ten-year government bonds. 
Figure 8

The distribution of crisis costs

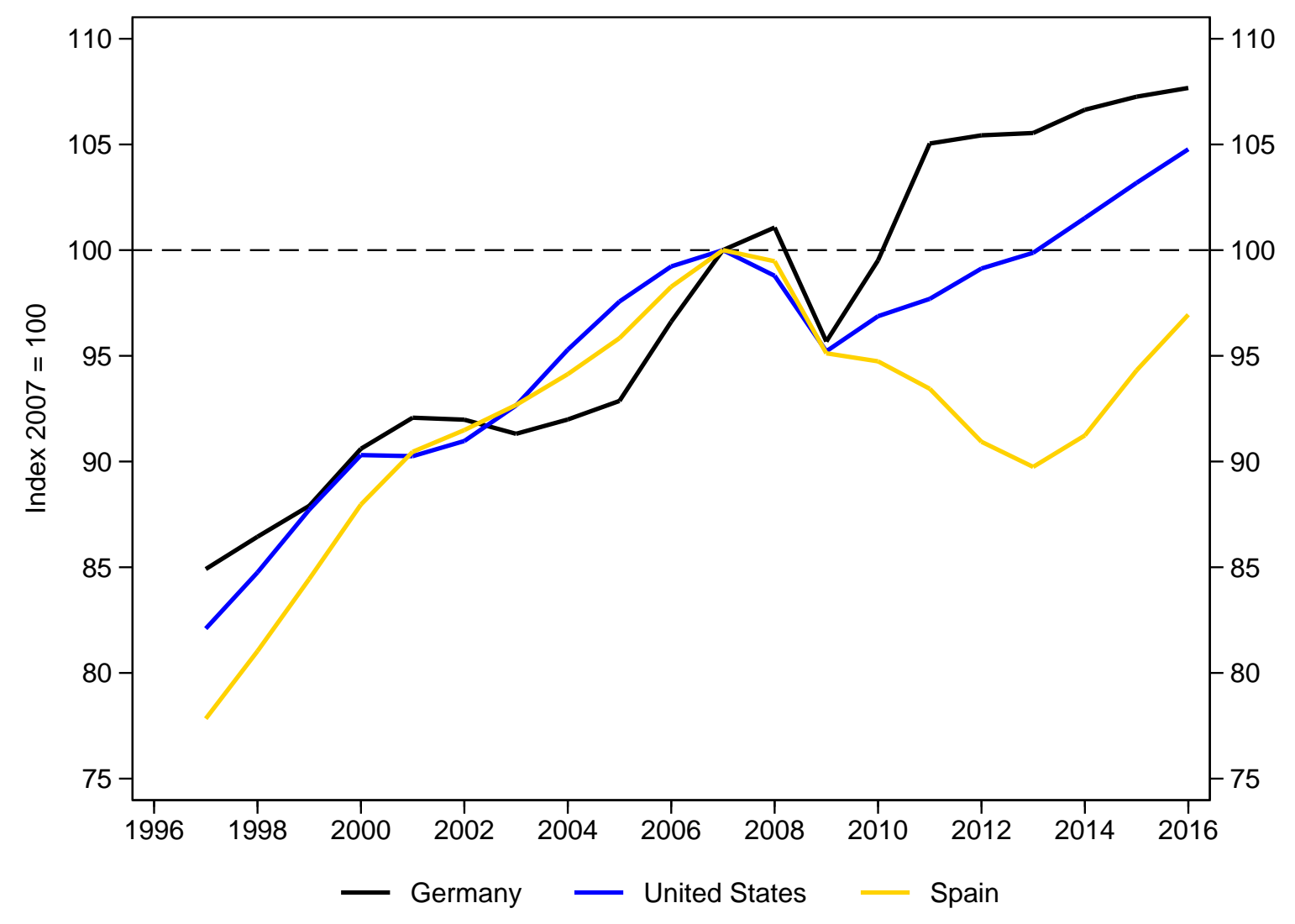

Notes: Real GDP per person, index 2007=100. Observation for 2016 reflects projections as presented in the IMF World Economic Outlook, April 2016. 


\section{IMFS WORKING PAPER SERIES}

\section{Recent Issues}

104 / $2016 \quad$ Helmut Siekmann

103 / $2016 \quad$ John B. Taylor

Volker Wieland

102 / $2016 \quad$ Tilman Bletzinger

Volker Wieland

$101 / 2016 \quad$ Helmut Siekmann

$100 / 2016$

99 / 2015

$98 / 2015$

97 / 2015

$96 / 2015$

$95 / 2015$

Athanasios Orphanides

$94 / 2015$

$93 / 2015$

92 / 2015

$91 / 2015$
Helmut Siekmann

Robert C. M. Beyer Volker Wieland

Helmut Siekmann

José María Liberti

Amit Seru

Vikrant Vig

Patrick Tuschl

Bettina Brüggemann

Jinhyuk Yoo

Tobias H. Tröger

Janis Skrastins

Vikrant Vig

Florian Hoffmann

Roman Inderst

Marcus Opp
Preis- und Finanzstabilität: der Primat der Politik, der rechtliche Rahmen und das „ökonomische Gesetz"

Finding the Equilibrium Real Interest Rate in a Fog of Policy Deviations

Forward guidance and "lower for longer": The case of the ECB

Ziele, Aufgaben und Befugnisse des Europäischen Systems der Zentralbanken (ESZB)

Schätzung des mittelfristigen Gleichgewichtszinses in den Vereinigten Staaten, Deutschland und dem Euro-Raum mit der Laubach-Williams-Methode

Exit, Exclusion, and Parallel Currencies in the Euro Area

Stellungnahme für die öffentliche Anhörung der Verfassungskommission des Landtags Nordrhein-Westfalen zur Schuldenbremse

Information, Credit, and Organization

Rechtsgrundlagen für die Vereinbarkeit von Finanzhilfen für Kreditinstitute mit dem Beihilferecht der EU im Rahmen der Finanzmarktkrise

Fear of Liftoff: Uncertainty, Rules and Discretion in Monetary Policy Normalization

Aggregate and Distributional Effects of Increasing Taxes on Top Income Earners

Regulatory Influence on Market Conditions in the Banking Union

How Organizational Hierarchy Affects Information Production

Regulating Deferred Incentive Pay 
$90 / 2015 \quad$ Helmut Siekmann

89 / 2015

87 / 2015

84 / 2014

$83 / 2014$

82 / 2014

$81 / 2014$

$80 / 2014$

$79 / 2014$

78 / 2014

77 | 2014
Tobias H. Tröger

Athanasios Orphanides

Helmut Siekmann

Florian Deuflhard

Dimitris Georgarakos

Roman Inderst

$$
\begin{aligned}
& \text { Falko Fecht } \\
& \text { Roman Inderst } \\
& \text { Sebastian Pfeil }
\end{aligned}
$$

Markus Behn

Rainer Haselmann

Thomas Kick

Vikrant Vig

Elena Afanasyeva

Jochen Güntner

Athanasios Orphanides

Markus Behn

Rainer Haselmann

Vikrant Vig

Volker Wieland

Maik Wolters

Hermann Remsperger

Michael Binder

Marcel Bluhm

Helmut Siekmann
The Legality of Outright Monetary

Transactions (OMT) of the European

System of Central Banks

(publ. in: Rövekamp / Bälz / Hilpert (eds.),

Central Banking and Financial Stability in

East Asia, 2015, pp. 101-123)

The Legal Framework for the European System of Central Banks (publ. in: Rövekamp / Bälz / Hilpert (eds.), Central Banking and Financial Stability in East Asia, 2015, pp. 43-86)

Financial Literacy and Savings Account Returns

A Theory of the Boundaries of Banks with Implications For Financial Integration and Regulation

The Political Economy of Bank Bailouts

Lending Standards, Credit Booms and Monetary Policy

Are Rules and Boundaries Sufficient to Limit Harmful Central Bank Discretion? Lessons from Europe

How Special Are They? - Targeting Systemic Risk by Regulating Shadow Banking

The Limits of Model-Based Regulation

Is there a threat of self-reinforcing deflation in the Euro area? A view through the lens of the Phillips curve

Der makroprudenzielle Komplex: der Prozess, das Schloss, das Urteil

What Happened in Cyprus? The Economic Consequences of the Last Communist Government in Europe

On the Conditional Effects of IMF Loan Program Participation on Output Growth

Zur Offenlegung der Bezüge von Sparkassenführungskräften im Internet 